\title{
EFFECT OF ZINC SULFATE AND / OR MANGANESE SULFATE SUPPLEMENTATION ON FRIESIAN CALVES PERFORMANCE . \\ EL-Nahas H. M.
}

Animal Production Res. Inst., Agric. Res. Center, Ministry of Agric. , Giza. Egypt.

\begin{abstract}
This study was conducted to investigate the effect of supplementation of zinc sulfate and / or manganese sulfate on the digestibility and ruminal activity, some blood parameters and productive performance of Friesian calves. Twenty calves with initial body weight of $262 \pm .7 \mathrm{~kg}$ in a 180 days experiment were chosen and divided into four similar groups (5 calves each). The control group was fed on concentrate feed mixture $(\mathrm{CFM})+$ berseem hay $(\mathrm{BH})+$ rice straw $(\mathrm{RS})$, while $1^{\text {st }}$ tested group was fed on the control ration $+40 \mathrm{mg}$ zinc sulfate $\left(\mathrm{ZnSO}_{4}\right) / \mathrm{kg} \mathrm{DMl}$, the $2^{\text {nd }}$ tested group was fed on the control ration $+40 \mathrm{mg}$ manganese sulfate $\left(\mathrm{MnSO}_{4}\right) /$ $\mathrm{kg} \mathrm{DMl}$ of and the $3^{\text {rd }}$ tested group was fed on the control ration $+(40 \mathrm{mg} \mathrm{ZnSO} 4+40$ $\mathrm{mg} \mathrm{MnSO} 4) / \mathrm{kg} \mathrm{DMI}$. Adding either zinc sulfate or manganese sulfate or mixture of both elements increased $(P<0.05)$ the nutrients digestibility and in turn the nutritive values (TDN and DCP). Adding zinc sulfate or manganese sulfate reduced ammonia-N and increased TVFA's. With respect to blood parameter, rations supplemented with Zinc or Mn sulfate appeared to higher total protein, albumine and lower globuline and urea concentration. Daily gain of the animals fed supplemented rations (tested groups) were higher than that of the control group being $0.969,0.883$ and $1.037 \mathrm{~kg}$ for animals fed rations supplemented with $\mathrm{Zn}, \mathrm{Mn}$ and both of $\mathrm{Zn}$ plus Mn sulfate, respectively. Consequently, feed efficiency was better for tested groups which was give more gain with less feed intake and lower feed cost.

It could be concluded that addition of $40 \mathrm{mg}$ zinc sulfate and / or manganese sulfate/kg DMI improved nutrients digestibility, economic efficiency and daily gain of Friesian calves.

Keywords: Friesian calves - zinc sulfate - manganese sulfate - feed intake digestibility -ruminal and blood parameters.- productive performance daily gain
\end{abstract}

\section{INTRODUCTION}

Minerals make up a small portion of an animals diet; however, they play important rolls in health, growth and reproduction (Ward and Lardy 2005). The importance of trace mineral nutrition relative to the maintenance of productivity and prevention of deficiency symptoms has been recognized for quite some time (Miller, 1981 and NRC, 2001). However, scientists in industry and academia have shown a more recent interest in understanding factors influencing trace mineral requirements and digestibility. Specifically, goals of more recent work include measuring potential benefits of trace mineral supplementation above predicted requirements upon dairy cattle health and productivity (Nocek et al., 2006; Siciliano-Jones et al., 2008 and Spears and Weiss, 2008). 


\section{EL-Nahas H. M.}

Trace mineral deficiencies can occur as a primary deficiency when mineral intake is inadequate or as a secondary deficiency when other factors in the diet interfere with the absorption and metabolism of the concerned trace elements (Olson et al.,1999).

Chemical analysis of the diet or an individual feed ingredient does not indicate the biological effectiveness of a nutrient in terms of trace minerals. Bioavailability may be defined as the proportion of an ingested mineral that is absorbed, transported to its site of action and converted to the physiologically active species (O'Dell 1983). Bioavailability of minerals particularly trace elements can be affected by a number of factors including animal species, physiological state, previous nutrition, interaction with other minerals and dietary nutrients, choice of standard source, chemical form and solubility of mineral element (Ammerman et al., 1995).

Manganese is linked to growth through its involvement in specific enzyme functions related to skeletal cartilage. Other results include poor growth rates (Ward and Lardy 2005).

Zinc plays a role in immune response, enzyme systems and hoof health. Zinc also plays an important role in DNA, RNA and protein production. Signs of deficiency include reduced feed intake and weight gain, excessive salivation, rough hair coat and eventually swelling of the feet and legs. Critical $\mathrm{Zn}$ deficiencies result in hair loss, thickening of skin, and lesions around the nose and mouth (Ward and Lardy 2005).

Zinc has a catalytic, coactive, or structural role in a wide variety of enzymes that regulate many physiological processes including metabolism, growth, and immune function (Vallee and Falchuk, 1993).

Feeding high levels of $\mathrm{Zn}$ from $\mathrm{Zn}$ sulfate altered ruminal fermentation and protozoa numbers in steers (Froetschel et al., 1990).

The objective of this study was to determine the effect of zinc sulfate $\left(\mathrm{ZnSO}_{4}\right)$ and manganese sulfate $\left(\mathrm{MnSO}_{4}\right)$ supplementation during the fattening period and also, investigate the digestion coefficients, nutritive values, ruminal and blood parameters and productive performance of Friesian beef calves.

\section{MATERIALS AND METHODS}

The present study was carried out during (2007) at EL-Karada Animal Production Research Station, Animal Production Research Institute, Agricultural Research Center, Ministry of Agriculture, Giza, Egypt.

\section{Experimental animals and rations}

Twenty Friesian calves, average body weight of $262 \pm 0.7 \mathrm{~kg}$ were randomly chosen and divided into four similar groups (5 calves each) according to body weight. The four groups were assigned at random to receive one of the four experimental rations. During the experimental trial, animals were fed the following experimental rations: 1- The control group was fed concentrate feed mixture $(\mathrm{CFM})+$ berseem hay $(\mathrm{BH})+$ rice straw (RS) without supplementation. The $1^{\text {st }}$ tested group was fed control ration + 40mg ZnSO$/ / \mathrm{kg} \mathrm{DMl}$. The $2^{\text {nd }}$ tested group was fed control ration + 
$40 \mathrm{mg} \mathrm{MnSO}_{4} / \mathrm{kg} \mathrm{DMI}$. The $3^{\text {rd }}$ tested group was fed the control ration + (40mg $\mathrm{ZnSO}_{4}$ and $40 \mathrm{mg} \mathrm{MnSO}_{4}$ )/kg DMI. Calves were individually fed their experimental rations in quantities according to their body weight in order to cover their requirements according to NRC (2001) allowances for beef calves. Rations were offered twice daily at 8 a.m. and 4 p.m. and water was offered freely.

\section{Digestibility and feeding trials}

The feeding trial lasted for 180 days. Live body weight changes and feed intake were recorded at two weeks interval. At the end of the feeding experiment, three calves from each group were chosen randomly to determine the digestion coefficients and nutritive values of the four experimental rations using acid insoluble ash techniques (A.I.A.) as a natural marker according to the method of Van Keullen and Young (1977). Representative samples of feedstuffs and feces were chemically analyzed according to A.O.A.C. (2000). Samples of CFM, BH, and RS were taken at the beginning, middle and the end of digestibility trials for chemical analyses. Daily fecal grab samples of nearly $200 \mathrm{~g}$ were taken from the rectum_of each animal at 12 hours apart during the collection period. The samples were composited, dried in a forced air oven at $65^{\circ} \mathrm{C}$ for 48 hours and ground. Nutrients digestion coefficients were calculated from the equations stated by Schneider and Flatt (1975).

DM digestibility $(\%)=100-[(100 \times($ AIA\% in feed $/ \mathrm{AIA} \%$ in faces $)]$

Nutrient digestibility $(\%)=100-[(100 \times$ (AIA $\%$ in feed / AIA \% in faces)(nutrient $\%$ in faces/nutrient $\%$ in feed)

\section{Rumen liquor and blood samples}

At the end of the digestion trials, rumen liquor samples were taken from the same three calves from each group which chosen randomly to determine the digestion coefficients and nutritive values of the four experimental rations at 0 time (before morning feeding) and at 3 and 6 hours after morning feeding using stomach tube. Samples were strained through four folds of cheese cloth. Ruminal pH value was determined immediately using Orian 680 digital $\mathrm{pH}$ meter. Samples were stored in dry clean glass bottles with added 2 drops of mercuric chloride and kept in deep freezer for chemical analysis. Concentrations of ammonia- $\mathrm{N}$ was determined according to the modified Semi-micro Kijeldehl digestion method A.O.A.C. (2000). The TVFA's were determined according to Eadie et al. (1967).

Blood samples were taken from the same three calves from each group which chosen randomly to determine the digestion coefficients and nutritive values of the four experimental rations from the jugular vein of each calve at 0 time (before morning feeding) at the same time of collection rumen liquor sampling by clean sterile needle into clean dry heparinized glass tubes, thereafter they were centrifuged for 15 minutes at 4000 r.p.m. to obtain blood plasma and stored at $-20{ }^{\circ} \mathrm{C}$ until analysis. Plasma samples were analyzed for total protein according to Weichselbaum (1946) and albumin colorimetrically according to Drupt (1974). The globulin was calculated by difference. The GOT, GPT and blood urea were measured using commercial diagnostic kits (Test combination, Pasteur lab.). Urea concentration was 


\section{EL-Nahas H. M.}

determined according to Fawcett and Scott (1960). Zinc and Manganese were determined according to Makino et al., (1982).

\section{Record keeping}

The initial body weight of individual male calves was recorded with platform balance, and thereafter at 15 days interval before morning feeding and watering in order to asses the changes in body weight and average daily gain. Body weight gain (BWG) and average daily gain (ADG) were obtained by calculation.

\section{Feed- and economic efficiencies}

Feed efficiency was calculated as the amounts of DM, TDN, and DCP per kg gain. Economic efficiency of gain was calculated as the ratio between the income of gain production and the cost of daily feed consumed as follows: Economic efficiency = Income of daily gain / cost of daily feed intake, where the price of $1 \mathrm{~kg}$ live body weight was $20 \mathrm{LE}$ and 1 Ton of CFM, RS, $\mathrm{BH}$ was 1600, 140 and 700 LE, respectivly according to year 2007 market price

\section{Statistical analyses}

The obtained data were statistically analyzed by general linear, model using ANOVA procedures of SAS (1985).The significant differences among treatments were tested using Duncan's multiple range test, (Duncan) (1955).

\section{RESULTS AND DISCUSSION}

\section{Chemical composition of feedstuffs}

Data of Table (1) show the chemical composition of the ingredients used to formulate the rations and the calculated composition of the experimental rations. It could be shown that the chemical composition of the ingredients such as $\mathrm{CFM}, \mathrm{BH}$ and $\mathrm{RS}$ was within the normal values which published by APRI (1997). Moreover, chemical composition of different experimental rations were nearly equal as shown in Table (1) .

Table (1): Chemical analysis of the ingredients and the experimental rations (On DM basis \%)

\begin{tabular}{|c|c|c|c|c|c|c|}
\hline Item & DM & OM & $\mathbf{C P}$ & EE & CF & \begin{tabular}{l|l|} 
Ash & NFE \\
\end{tabular} \\
\hline${ }^{\star} \mathrm{CFM}$ & 90.07 & 93.37 & 16.84 & 2.76 & 12.59 & \begin{tabular}{l|l}
6.63 & 61.18
\end{tabular} \\
\hline Berseem hay ( $3^{\text {ed }}$ cut $)$ & 89.22 & 87.86 & 14.74 & 3.71 & 29.33 & 12.1440 .08 \\
\hline Rice straw & 89.41 & 82.98 & 3.23 & 1.44 & 36.71 & 17.0241 .60 \\
\hline \multicolumn{7}{|l|}{ Calculated experimental ration: } \\
\hline Control & 89.67 & 88.75 & 12.40 & 2.65 & 23.23 & $|11.25| 50.47$ \\
\hline Control+ $40 \mathrm{mg} \mathrm{Zn}$ sulfate & 89.66 & 88.60 & 12.23 & 2.64 & 23.72 & 11.4050 .01 \\
\hline Control+ $40 \mathrm{mg} \mathrm{Mn}$ sulfate & 89.66 & 88.59 & 12.24 & 2.64 & 23.71 & 11.4150 .00 \\
\hline Control $+40 \mathrm{mg} \mathrm{Zn}+40 \mathrm{mg}$ Mn sulfate & 89.65 & 88.56 & 12.21 & 2.64 & 23.78 & $11.44 \mid 49.93$ \\
\hline & & & & & & \\
\hline
\end{tabular}

\section{Digestibility and Nutritive values}

Data presented in table (2) indicated that adding mixture of both of zinc sulfate and manganese sulfate to the tested rations significantly $(P<0.05)$ 
increased all nutrients digestibility and hence nutritive values (TDN and DCP) compared to control ration. The highest digestibility coefficient of DM, $\mathrm{OM}$ and NFE were recorded with zinc sulfate ration followed by manganese sulfate ration. This might be attributed to the increase of protein and energy utilization in the rumen (Valdes et al., 2000 and Salem,2003). Feeding high levels of $\mathrm{Zn}$ from $\mathrm{Zn}$ sulfate altered ruminal fermentation and protozoa numbers in steers (Froetschel et al., 1990). Generally, supplemented ration with zinc and manganese sulfate tended to higher digestibility.

These results are in harmony with those obtained by, Shakweer et al., (2010). They found that the addition of zinc sulfate or zinc methionine to the ration of Friesian suckling calves and growing Friesian calves increased the digestibility of DM, OM, CP and CF also nutritive values (TDN and DCP) compared with those of the control group. Mousa and El-Sheikh, (2004) found that both apparent digestibility coefficients of all nutrients and feeding values as TDN and DCP were significantly $(P<0.05)$ increased by different levels of zinc sulfate supplementation to the ration of buffalo-calves. Durand and Kawashima, (1980) concluded that addition of 50mg Zinc / $\mathrm{kg}$ DMI of rations showed optimize microbial metabolism and consequently led to improvement of the digestibility of DM, OM, CP, CF, EE and NFE.

Mondal et al. (2008), reported that supplementation of $\mathrm{Cu}, \mathrm{Fe}, \mathrm{Zn}$ and $\mathrm{Mn}$ improved $(\mathrm{P}<0.05)$ digestibility of DM,CP,CF, ash, EE and NFE compared to the unsupplemented control ration.

Table (2) : Digestion coefficients and nutritive values of experimental rations fed to Friesian calves supplemented with $\mathrm{ZnSO}_{4}$ and / or $\mathrm{MnSO}_{4}$

\begin{tabular}{|c|c|c|c|c|c|}
\hline \multirow[b]{2}{*}{ Item } & \multicolumn{4}{|c|}{ Experimental rations } & \multirow[b]{2}{*}{$\begin{array}{c}\text { SE } \\
\pm\end{array}$} \\
\hline & control & $\begin{array}{c}\text { Control + } \\
40 \mathrm{mg} \mathrm{Zn} \\
\text { sulfate/ kg } \\
\text { DMI }\end{array}$ & $\begin{array}{c}\text { Control + } \\
40 \mathrm{mg} \text { Mn } \\
\text { sulfate/ kg } \\
\text { DMI }\end{array}$ & $\begin{array}{c}\text { Control } \\
+40 \mathrm{mg} \\
\text { (each) Zn } \\
\& \mathrm{Mn} \\
\text { sulfate/ } \\
\mathrm{Kg} \mathrm{DMI}\end{array}$ & \\
\hline Digestion coefficients,(\%) & & & & & \\
\hline DM & $\begin{array}{l}62.25^{\mathrm{c}} \\
64.41^{\mathrm{c}}\end{array}$ & $\begin{array}{l}70.71^{\mathrm{a}} \\
7172^{\mathrm{a}}\end{array}$ & $\begin{array}{l}66.36^{\mathrm{b}} \\
67.40^{\mathrm{b}}\end{array}$ & $\begin{array}{l}69.67^{\mathrm{a}} \\
70.45^{\mathrm{a}}\end{array}$ & $\begin{array}{l}.658 \\
744\end{array}$ \\
\hline $\mathrm{CP}$ & $61.14^{\mathrm{d}}$ & $71.50^{\mathrm{b}}$ & $66.87^{\mathrm{C}}$ & $74.58^{\mathrm{a}}$ & .647 \\
\hline CF & $57.26^{\mathrm{c}}$ & $67.77^{\mathrm{a}}$ & $64.38^{\mathrm{b}}$ & $69.79^{\mathrm{a}}$ & .798 \\
\hline EE & $67.15^{\mathrm{b}}$ & $74.79^{\mathrm{a}}$ & $66.65^{\mathrm{b}}$ & $77.65^{\mathrm{a}}$ & 1.726 \\
\hline NFE & $64.69^{\mathrm{b}}$ & $70.84^{\mathrm{a}}$ & $66.67^{\mathrm{b}}$ & $67.76^{\mathrm{a}}$ & 1.093 \\
\hline Nutritive values, \% & $5753^{\mathrm{c}}$ & $6468^{a}$ & $6013^{b}$ & $6514^{\mathrm{a}}$ & 640 \\
\hline DCP & $7.58^{\mathrm{d}}$ & $8.75^{\mathrm{ab}}$ & $8.18^{\mathrm{C}}$ & $9.11^{\mathrm{a}}$ & .085 \\
\hline
\end{tabular}

a , b, c, and d: Means in the same row followed by different superscripts are significantly different $(P<0.05)$.

\section{Rumen liquor parameters}

Ruminal $\mathrm{pH}$ values (Table 3 ) were almost similar among all the experimental rations at 0,3 and 6 hours post feeding even the control ration showing no significant differences. These results are in line with those 


\section{EL-Nahas H. M.}

obtained by Robinson et al. (2002) and Shakweer et al. (2010). However, Arelovich et al., (2000) reported that $\mathrm{pH}$ at $2 \mathrm{hrs}$. after feeding was linearly decreased, but at 6.00 hrs. was linearly $(P<0.05)$ increased by adding zinc sulfate

Over the three sampling times, the concentrations of $\mathrm{NH}_{3} \mathrm{~N}$ in Table (3) reduced with zinc sulfate addition compared to that of the control ration during the different period, while it was the highest concentrations by manganese sulfate addition group followed by the mixture of the $\mathrm{Zn}$ and $\mathrm{Mn}$ sulfate addition group. These results are in accordance with those obtained by Skakweer et al. (2010). Also, ruminal ammonia- $\mathrm{N}$ was linearly decreased $(\mathrm{P}<0.05)$ by adding zinc sulfate as presented by Arelovich et al., (2000). This might be due to that adding zinc sulfate to the ration depressed urease activity directly or it might inhibit growth and reduce the population of ureolytic bacteria as stated by Arelovich et al. (2000) .

Table (3): The Effect of $\mathrm{ZnSO}_{4}$ and/ or $\mathrm{MnSO}_{4}$ supplementation on ruminal $\mathrm{pH}, \mathrm{NH}_{3}$, TVFA's values.

\begin{tabular}{|c|c|c|c|c|c|c|}
\hline \multirow[b]{2}{*}{ Item } & & \multicolumn{4}{|c|}{ Experimental rations } & \multirow[b]{2}{*}{$\begin{array}{c}\text { SE } \\
\pm\end{array}$} \\
\hline & Time & Control & $\begin{array}{c}\text { Control+40 } \\
\text { mg }\end{array}$ & $\begin{array}{c}\text { Control + } \\
40 \mathrm{mg} \\
\text { Mn sulfate/ } \\
\text { kg DMI }\end{array}$ & $\begin{array}{c}\text { Control +40 } \\
\text { mg (each) } \\
\text { Zn \&Mn } \\
\text { sulfate/ } \\
\text { kg DMI }\end{array}$ & \\
\hline \multirow[t]{3}{*}{$\mathrm{pH}$} & 0 & $6.58^{\mathrm{a}}$ & $6.48^{a}$ & $6.50^{\mathrm{a}}$ & $6.57^{\mathrm{a}}$ & .092 \\
\hline & 3 & $6.28^{\mathrm{a}}$ & $6.18^{\mathrm{a}}$ & $6.07^{\mathrm{a}}$ & $6.17^{\mathrm{a}}$ & .085 \\
\hline & 6 & $6.48^{\mathrm{a}}$ & $6.38^{a}$ & $6.48^{a}$ & $6.38^{\mathrm{a}}$ & .076 \\
\hline \multirow[t]{3}{*}{$\mathrm{NH}_{3} \mathrm{~N}(\mathrm{mg} / 100 \mathrm{ml} \mathrm{RL})$} & 0 & $20.80^{\mathrm{ab}}$ & $19.80^{\mathrm{ab}}$ & $21.14^{\mathrm{a}}$ & $18.77^{\mathrm{b}}$ & .622 \\
\hline & 3 & $28.60^{\mathrm{a}}$ & $25.60^{\mathrm{bc}}$ & $26.63^{b}$ & $24.63^{c}$ & .361 \\
\hline & 6 & $23.04^{\mathrm{c}}$ & $20.04^{d}$ & $28.63^{a}$ & $25.63^{b}$ & .455 \\
\hline \multirow[t]{3}{*}{ TVFA's(meq/100ml RL) } & 0 & $6.88^{\mathrm{a}}$ & $7.28^{a}$ & $7.08^{\mathrm{a}}$ & $7.38^{\mathrm{a}}$ & .194 \\
\hline & 3 & $8.98^{c}$ & $9.98^{\mathrm{ab}}$ & $9.78^{b}$ & $10.23^{a}$ & .108 \\
\hline & 6 & $6.42^{c}$ & $7.12^{\mathrm{b}}$ & $6.52^{c}$ & $7.32^{\mathrm{a}}$ & .061 \\
\hline
\end{tabular}

a , b, c and d: Means in the same row followed by different superscripts are significantly different $(\mathrm{P}<0.05)$

On the other hand, the TVFA's was similar for all the experimental rations even control ration at Zero time. Samples taken at 3 and $6 \mathrm{hrs}$ were significantly $(\mathrm{P}<0.05)$ higher for the ration supplemented by the mixture of the $\mathrm{Zn}$ and $\mathrm{Mn}$ sulfate followed by ration supplemented with zinc sulfate followed by ration supplemented with Mn sulfate. Recorded higher TVFA's might be due to the increase of apparent digestibility of organic matter. These results are in accorde with Arelovich et al., (2000) and Shakweer et al., (2010) who reported that the increased proportion of propionate in ruminal VFA's leads to an increased energetic efficiency of ruminal fermentation which might explain the consistent benefits obtained from addition of chelated zinc supplement.

\section{Blood plasma parameters}

The data in Table (4) showed that addition mixture of zinc sulfate and manganese sulfate resulted in significantly $(P<0.05)$ higher each of total protein, albumin, globulin, $\mathrm{Zn}$ and $\mathrm{Mn}$ that those recorded with control ration. However, urea concentration in blood plasma was significantly the lowest by adding mixture of $\mathrm{ZnSO}_{4}$ and $\mathrm{MnSO}_{4}$ followed by ration supplemented with 
$\mathrm{MnSO}_{4}$ then ration supplemented with $\mathrm{ZnSO}_{4}$ compared to the control ration which had the highest urea concentration. Also, it could be noticed that adding either Zinc or Mn sulfate to rations tended to higher the previous parameter, except urea concentration. These results are in line with those obtained by Shakweer et al. (2010) who found that plasma total protein, plasma albumin, plasma globulin and $\mathrm{Zn}$ concentrations of Friesian suckling calves and growing Friesian calves which were supplemented zinc sulfate or zinc methionine were higher than the control ration. Mousa and EL-Sheikh (2004) indicated that zinc sulfate addition increased total protein and globulin concentration, while it decreased albumin and urea concentration in blood serum of buffalo-calves.

Table (4): Effect of $\mathrm{ZnSO}_{4}$ and/ or $\mathrm{MnSO}_{4}$ supplementation on some blood parameters.

\begin{tabular}{|c|c|c|c|c|c|}
\hline \multirow[b]{2}{*}{ Item } & \multicolumn{4}{|c|}{ Experimental rations } & \multirow[b]{2}{*}{$\begin{array}{c}\text { SE } \\
\pm\end{array}$} \\
\hline & control & $\begin{array}{l}\text { Control+40 mg } \\
\begin{array}{c}\text { Zn sulfate/ kg } \\
\text { DMI }\end{array}\end{array}$ & $\begin{array}{c}\text { Control + } \\
40 \mathrm{mg} \\
\text { Mn sulfate/ } \\
\text { kg DMI }\end{array}$ & $\begin{array}{c}\text { Control +40 } \\
\text { mg (each) } \\
\text { Zn \&Mn } \\
\text { sulfate/ kg } \\
\text { DMI }\end{array}$ & \\
\hline Total protein g/dl & $7.96^{\mathrm{d}}$ & $8.66^{\mathrm{b}}$ & $8.23^{\mathrm{C}}$ & $8.93^{\mathrm{a}}$ & .017 \\
\hline Albumin $\mathrm{g} / \mathrm{dl}$ & $4.72^{\mathrm{C}}$ & $5.22^{\mathrm{ab}}$ & $4.95^{\mathrm{bc}}$ & $5.35^{\mathrm{a}}$ & .089 \\
\hline Globulin g/dl & $3.25^{\mathrm{b}}$ & $3.45^{\mathrm{ab}}$ & $3.28^{\mathrm{ab}}$ & $3.58^{\mathrm{a}}$ & .093 \\
\hline urea mg/dl & $36.75^{\mathrm{a}}$ & $32.75^{\mathrm{ab}}$ & $31.75^{\mathrm{b}}$ & $24.75^{\mathrm{C}}$ & 1.40 \\
\hline Zinc mg/dl & $0.69^{d}$ & $0.89^{\mathrm{b}}$ & $0.79^{c}$ & $0.98^{\mathrm{a}}$ & .005 \\
\hline Manganese $\mathrm{mg} / \mathrm{dl}$ & $0.25^{\mathrm{b}}$ & $0.21^{\mathrm{c}}$ & $0.27^{b}$ & $0.31^{\mathrm{a}}$ & .007 \\
\hline
\end{tabular}

$a, b, c$ and d: Means in the same row followed by different superscripts are significantly different $(P<0.05)$.

Increasing in plasma globulin by zinc supplementation might be due to refelect the rise in total protein as reported by El-Masry and Habeeb (1989) and El-Masry and Yousef (1998). Also, Malcolm-callis et al., (2000) found that zinc addition $(30 \mathrm{mg} / \mathrm{kg} \mathrm{DMI})$ for beef steers significantly increased serum globulin concentration. Similar observation was recorded by Olson et al (1999), who reported that supplementation of trace minerals containing $\mathrm{Mn}$ and $\mathrm{Zn}$ in organic and inorganic forms raised the serum level of respective minerals compared to the control but within sources only plasma $\mathrm{Zn}$ level was higher from organic than inorganic.

\section{Growth performance}

Data in Table (5) revealed that addition of a mixture of zinc sulfate and manganese sulfate with rate of $40 \mathrm{mg} / \mathrm{kg}$ DMl significantly $(P<0.05)$ increased the average daily gain and the total gain followed by ration containing $\mathrm{Zn}$ sulfate $\left(\mathrm{ZnSO}_{4}\right)$ then that supplemented with $\mathrm{Mn}$ sulfate $\left(\mathrm{MnSO}_{4}\right)$ compared to the control ration.

The improvment in growth performance with zinc supplementation ration was not only due to its importance through acting as a component and activator to more than 200 metalloenzymes and hormones (Riordan and Vallee 1976), but also its role in improving acid - base balance as stated by Halhn and Baker (1988) and digestive enzymes activities by Izhboldina 


\section{EL-Nahas H. M.}

(1994). The present results are in agreement with those of Goetsch et al. (1990) who found that the daily gain was higher $(P<0.05)$ with supplemented ration ( $4 \mathrm{~g}$ zinc/d/animal ) than that without zinc supplementation by beef steers. Shakweer et al. (2010) found that the daily gain of Friesian suckling and growing Friesian calves was higher $(P<0.05)$ with supplement of $40 \mathrm{mg}$ zinc sulfate or zinc methionine than control group. Moreover, Zeedan et al. (2008) stated that daily gain and body weight gain were significantly higher with buffalo-calves fed $40 \mathrm{mg}$ and $80 \mathrm{mg}$ zinc methionine compared to the control ration. Mousa and EL-Sheikh (2004) found that the addition of zinc at different concentrations increased daily gain of buffalo-calves when compared to the unsupplemented control group.

On the other hand, Greene et al. (1988) reported that there was no significant difference in growth rate and feed conversion of steers fed zinc oxide or zinc methionine in excess of requirement. Moreover, Kessler et al. (2003) found that zinc supplementation to fattening bulls in the form Zinc oxide, Znic proteinate and Zinc polysaccharide did not have significant impact on growth performance and feed conversion.

Bioavailability may be defined as the proportion of an ingested mineral that is absorbed, transported to its site of action and converted to the physiologically active species (O'Dell 1983). Bioavailability of minerals particularly trace elements can be affected by a number of factors including animal species, physiological state, previous nutrition, interaction with other minerals and dietary nutrients, choice of standard source, chemical form and solubility of mineral element (Ammerman et al., 1995). Feeding high levels of $\mathrm{Zn}$ from $\mathrm{Zn}$ sulfate altered ruminal fermentation and protozoa numbers in steers (Froetschel et al., 1990).

Manganese is linked to growth through its involvement in specific enzyme functions and also Zinc plays an important role in immune response, enzyme systems, an important role in DNA, RNA and protein production. Signs of deficiency include reduced feed intake and weight gain (Ward and Lardy 2005). Zinc has a catalytic, coactive, or structural role in a wide variety of enzymes that regulate many physiological processes including metabolism, growth, and immune function (Vallee and Falchuk, 1993).

Mondal et al. (2008), found could be established between that no significant $(P>0.05)$ difference among the various treatment groups in respect to body weight gain (BWG) and average daily gain (ADG) during the first 30 days of the trial, but after 30days throughout the experimental period (BWG) and (ADG) were significantly improved in all mineral supplemented groups compared to the control group.

This is also consistent with the findings of Olson et al (1999) and Muchlenbain et al (2001) who revealed that different trace minerals, particularly $\mathrm{Cu}, \mathrm{Mn}, \mathrm{Zn}$, function biochemically as a component of several metalloenzymes and as a cofactor for numerous other enzymes. Zapsalis and Beck 1985, Sorensen 1987 and Boland 2003 revealed that it is possible that different trace minerals enhance growth of calves by stimulating activities of enzymes involved in nutrient utilization. 
Table(5): Feed intake, feed efficiency, body weight gain (BWG) and average daily gain (ADG) of Friesian calves given $\mathrm{ZnSO}_{4}$ and/or $\mathrm{MnSO}_{4}$ supplementation .

\begin{tabular}{|c|c|c|c|c|c|}
\hline \multirow[b]{2}{*}{ Item } & \multicolumn{4}{|c|}{ Experimental rations } & \multirow{2}{*}{$\begin{array}{c}\text { SE } \\
\pm\end{array}$} \\
\hline & Control & $\begin{array}{c}\text { Control+40 mg } \\
\text { Zn sulfate/kg DMI }\end{array}$ & $\begin{array}{c}\text { Control+40mg } \\
\text { Mn sulfat/kg } \\
\text { DMI }\end{array}$ & $\begin{array}{l}\text { Control+40mg } \\
\text { (each) Zn\&Mn } \\
\text { sulfate/kg DMI }\end{array}$ & \\
\hline No. of animal & 5 & 5 & 5 & 5 & \\
\hline Duration /days & 180 & 180 & 180 & 180 & \\
\hline Initial body weight, $\mathrm{kg}$ & $261.6^{\mathrm{a}}$ & $262.3^{b}$ & $262.7^{\mathrm{a}}$ & $261.3^{a}$ & 6.17 \\
\hline Final body weight, $\mathrm{kg}$ & $395.3^{\mathrm{d}}$ & $436.7^{b}$ & $421.7^{c}$ & $448.0^{\mathrm{a}}$ & 3.28 \\
\hline Total gain, $\mathrm{kg}$ & $133.7^{\mathrm{C}}$ & $174.4^{\text {ab }}$ & $159.0^{b}$ & $186.7^{\mathrm{a}}$ & 7.58 \\
\hline Average daily gain, (g/h/day) & $0.743^{c}$ & $0.969^{\mathrm{ab}}$ & $0.883^{b}$ & $1.037^{\mathrm{a}}$ & .042 \\
\hline \multicolumn{5}{|c|}{ (on DM basis) Average daily feed intake } & \\
\hline CFM, ( kg/h/day) & 3.08 & 3.21 & 3.15 & 3.28 & \\
\hline Berseem hay, ( kg/h/day) & 1.62 & 1.87 & 1.83 & 1.93 & \\
\hline Rice straw , (kg/h/day) & 1.81 & 2.08 & 2.03 & 2.14 & \\
\hline Total intake, (kg/h/day) & 6.51 & 7.16 & 7.01 & 7.35 & \\
\hline Total TDN, (kg/h/day) & 3.745 & 4.631 & 4.215 & 4.787 & \\
\hline Total DCP, (kg/h/day) & 0.493 & 0.627 & 0.573 & 0.669 & \\
\hline \multicolumn{5}{|c|}{ Feed efficiency } & \\
\hline $\mathrm{Kg} \mathrm{DM} / \mathrm{kg}$, gain & 8.8 & 7.4 & 7.9 & 7.1 & \\
\hline $\mathrm{Kg}$ TDN/ kg, gain & 5.0 & 4.8 & 4.8 & 4.6 & \\
\hline Kg DCP/kg,gain & 0.66 & 0.65 & 0.65 & 0.65 & \\
\hline
\end{tabular}

$A, b, c$ and d: Means in the same row followed by different superscripts are significantly different $(P<0.05)$.

\section{Feed intake and feed efficiency}

Daily feed intake as $\mathrm{kg}$ DM, TDN and DCP/ head are shown in table (5) .The highest intake and the efficiency were recorded with addition of mixture of $40 \mathrm{mg} \mathrm{ZnSO} 4+40 \mathrm{mg} \mathrm{MnSO}_{4} / \mathrm{kg}$ DMl followed by ration supplemented with $40 \mathrm{mg} \mathrm{ZnSO}$ then ration supplemented with $\mathrm{MnSO}_{4}$ compared to the control ration. Regarding feed efficiency expressed as a mounts of DM, TDN and DCP per $1 \mathrm{~kg}$ gain, it could be noticed that the ration containing mixture of $40 \mathrm{mg} \mathrm{ZnSO} 4+40 \mathrm{mg} \mathrm{MnSO} 4$ had the best values $(7.1,4.6,0.65)$ followed by ration supplemented with $40 \mathrm{mg} \mathrm{ZnSO} 4$ $(7.4,4.8,0.65)$ then ration supplemented with $40 \mathrm{mg} \mathrm{MnSO}_{4}(7.9,4.8,0.65)$ compared to the control ration $(8.8,5.0,0.66)$, respectively.

Results here are in agreement with those of Shakweer and et al. (2010) who found that feed efficiency was improved with adding zinc sulfae or zinc methionine supplementation for growing Friesian calves. Mousa and El-Sheikh (2004) reported that feed intake and feed efficiency were improved with adding $40 \mathrm{mg}$ zinc sulfate $/ \mathrm{kg} \mathrm{DMI}$ for buffalo-calves compared to the control group.

\section{Economic efficiency}

The economical study in Table (6) showed that the feed cost $/ \mathrm{kg}$ weight gain (L.E.) of control group was $(9.68 \mathrm{~L}$.E $/ \mathrm{kg}$ gain) while, the supplemented groups were $7.12,8.39$ and $10.86 \mathrm{LE} / \mathrm{kg}$ gain for ration supplemented with $\mathrm{ZnSO}_{4}+\mathrm{MnSO}_{4}$ followed by that supplemented with $\mathrm{MnSO}_{4}$ then that supplemented with $\mathrm{ZnSO}_{4}$, respectively. The best economic efficiency was detected with ration supplemented with $\left(\mathrm{ZnSO}_{4}+\mathrm{MnSO}_{4}\right)$ 


\section{EL-Nahas H. M.}

with rate of $40 \mathrm{mg}$ (each) $/ \mathrm{kg} \mathrm{DMI} \mathrm{(2.8 \% )} \mathrm{followed} \mathrm{by} \mathrm{ration} \mathrm{supplemented}$ with $\mathrm{ZnSO}_{4}(2.6 \%)$ then ration supplemented with $\mathrm{MnSO}_{4}(2.4 \%)$ compared to the control ration $(2.1 \%)$.

Economic efficiency $(\%)=$ Price of daily gain (L.E)

Average daily feed cost (L.E.)

Table (6): Economic efficiency of Friesian calves fed on ration supplemented with $\mathrm{ZnSO}_{4}$ and/or $\quad \mathrm{MnSO}_{4}$ supplementation .

\begin{tabular}{|l|c|c|c|c|}
\hline Item & control & $\begin{array}{c}\text { Control+40mg } \\
\text { Zinc } \\
\text { sulfate/kgDMI }\end{array}$ & $\begin{array}{c}\text { Control + 40mg } \\
\text { Mn sulfat/kgDMI }\end{array}$ & $\begin{array}{c}\text { Control + } \\
\text { 40mg (each) } \\
\text { Zn\&Mn } \\
\text { sulfate/kgDMI }\end{array}$ \\
\hline Daily feed intake (as fed),kg & & & & \\
\hline \hline CFM & 3.48 & 3.57 & 3.50 & 3.65 \\
\hline Berseem hay (3 ${ }^{\text {rd }}$ cut) & 1.88 & 2.13 & 2.07 & 2.18 \\
\hline Rice straw & 2.12 & 2.33 & 2.27 & 2.40 \\
\hline Total feed intake, kg/h/d & 7.48 & 8.03 & 7.84 & 8.23 \\
\hline Zinc supplement , g/h/d & -- & .11 & -- & .11 \\
\hline Mn supplement, g/h/d & -- & -- & .13 & 7.81 \\
\hline Total daily feed cost (L.E.)/h/d & 7.19 & 7.56 & 7.41 & 1.097 \\
\hline Average daily gain, kg/h/d & 0.743 & 0.969 & 0.883 & 7.12 \\
\hline Feed cost/kg gain (L.E.) & 9.68 & 10.86 & 8.39 & 21.94 \\
\hline Price of daily gain (L.E.) & 14.86 & 19.38 & 17.66 & 14.82 \\
\hline Economical return (L.E/h/d) & 5.18 & 8.52 & 9.27 & 2.8 \\
\hline Economic efficiency(\%) & 2.1 & 2.6 & 2.4 & \\
\hline Calculation based on the follong & & & \\
\hline
\end{tabular}

Calculation based on the following price in Egyptian pound (L.E.) per ton according to year 2007 market price. The price of $1 \mathrm{~kg}$ live body weight $=20 \mathrm{LE}$, Concentrate feed mixture $(C F M)=1600$ L.E./ton, Berseem hay=700 L.E./ton, Rice straw=140 L.E./ton, zinc sulfate $=30$ L.E./kg, manganese sulfate $=30$ L.E. $/ \mathbf{k g}$,

\section{Conclusion}

From these results, it could be concluded that ration containing 40 mg $\mathrm{ZnSO}_{4}$ plus $40 \mathrm{mg} \mathrm{MnSO}_{4}$ tended to higher digestibility coefficient, increase daily gain, improved feed efficiency and decrease feed cost to give $1 \mathrm{~kg}$ gain of Friesian calves. Moreover, using Zinc sulfate appeared higher performance that using $\mathrm{Mn}$ sulfate with the previous parameter.

\section{REFERENCES}

Ammerman C. B.; D. H. Baker and A. J. Lewis (editors) (1995). Bioavailability of nutrients for animals: amino acids, minerals and vitamins. Academic Press, New York, NY.

A.O.A.C.(2000). Association of Official Analytical Chemists . Official Methods of Analysis , Washington, D.C.,USA.

A.P.R.I.(1997). Animal Nutrition book (Scientific and applied) $1^{\text {st }}$ issue .Agriculture Research Center, Ministry of Agriculture, Cairo, Egypt. 
Arelovich H. M.; F.N. Owens; G.W. Horn and J.A.Vizcarra(2000). Effect of supplemented zinc and manganese on ruminal fermentation, forage intake and digestion by cattle fed prairie hay and urea. J. Anim. Sci., 78: 2972-2979.

Boland P. M. (2003). Trace minerals in Production and reproduction In Dairy Cows. Advances in Dairy Technology 15: 323-324

Drupt E. (1974). Colorimetric determination of albumin. Biol. J. 9:777.

Duncan D. B. (1955). Multiple range and multiple F. test . Biometricies, 11:142.

Durand M. and R. Kawashima (1980). Influence of minerals in rumen microbial digestion In: Ruckebusch and P.Thivend (Eds.). Digestive Physiology and Metabolism in Ruminants. Pp. 375- 408. AVI publ. Co., Inc., Westport, ct.

Eadie J. M. P.; N. Hobson and S. O. Mann (1967). A note on some comparisons between the rumen content of barley fed steers and that of young calves fed on high concentrate rations. J. Anim. Prod., 9:247.

El-Masry K. A. and A. A. Habeeb (1989). Thyroid function in lactating Friesian cows and water buffaloes under winter and summer Egyptian conditions. Proc. Of $3^{\text {rd }}$ Egypt-British Conf. On Anim. Fish and Poult. Prod., vol. 20 , Alex ,Egypt., p:613.

El-Masry K. A. and H. M. Yousef (1998). Effect of supplemental Zn and Vitamin $A$ on some blood biochemical and immune indices releted to growth performance in growing calves. Proc. Of first conf. On Anim. Prod. And Health. In semi-Arid Areas, AL-Arish. North Sinai, Egypt $p$. 139.

Fawcett J. K. and J. E. Scott (1960). Colorimetric determination of urea .An. J. Clin.Path. B,156.

Froetschel M. A. ; A. C. Martin; H .E. Amos and J. J. Evans (1990). Effect of zinc sulfate concentration and feeding frequency on ruminal protozoal numbers, fermentation pattern and amino acid passage in steers. J. Anim. Sci., 68: 2874.

Goetsch A. L.; G. E. Murphy; E. W. Grant; L. A. Forster; Jr. D. L. Galloway; Sr. C. P. West and Z. B. Johnson (1990). Effect of animal and supplement characteristics on average daily gain of grazing beef cattle .J. Anim. Sci., 69:433.

Greene L.W.; D.K. Lunt; F. M. Byers; N. K. Chirase; C. E. Richmond; E. Knutson; and G. T. Schelling (1988). Performance and carcass quality of steers supplemented with zinc oxide or zinc methionine .J.Anim.Sci.,66:1818-1823.

Halhn J. D. and D. H. Baker (1988). Growth and plasma zinc responses of young pigs fed pharmacological levels of zinc. J. Anim. Sci., 71:3020.

Izhboldina S. I. (1994). Trace elements during rearing and fattening of young bulls. Zootekhniya 33(3):14.

Kessler J.; I. Morel; P, A. Dufey; A. Gutzwiller; A. Stern and H. Geyer (2003). Effect of organic zinc source on performance,zinc status and carcass, meat and claw quality in fatting bulls. Livestock Prod. Sci., 81:161-171. 


\section{EL-Nahas H. M.}

Makino T.; M. Saito; D. Horiguchi and K. Kina (1982). Colorimetric determination of zinc Clinica. Chimica. Acta., 120:127-135.

Malcolm-Callis K. J; G. C. Duff; S. A. Gunter; E. B. Kegley and D. A. Vermeire (2000). Effect of supplemental zinc concentration and source on performance, carcass characteristics, and serum values in finishing beef steers. J. Anim. Sci., 78:2801.

Miller, W. J. 1981. Mineral and vitamin nutrition of dairy cattle. J. Dairy Sci., 64:1196-1206.

Mondal S.; S. K. Paul; B. Bairagi; M. C. Pakhira and P. Biswas (2008). Comparative studies of reducing level of organic with inorganic trace minerals supplementation on the performance, nutrient digestibility and mineral balance in cross-bred male calves. Livestock Research for Rural Development 20 (7)

Mousa Kh. M. M. and S. M. EL-Sheikh (2004). Effect of different levels of zinc supplementation on utilization of non-protein nitrogen and production performance of buffalo-calves. J. Agric. Sci. Mansoura Univ., 29(7) 3779-3793.

Muchlenbein E L; D. R. Brink; G. H. Deutscher; M. P. Carlson and A. B. Johnson (2001). Effect of inorganic and organic copper supplemented to first calf cows on cow production and calf health and performances. J. Anim. Sci., 79: 1650-1659 .

Nocek J. E.; M.T. Socha and D. J. Tomlinson (2006). The effect of trace mineral fortification level and source on performance of dairy cattle. J. Dairy Sci., 89:2679-2693.

NRC. (2001). Nutrient Requirements of Dairy Cattle. 7th rev. ed. Natl. Acad. Sci., Washington, DC.

O'Dell B. L. (1983). Bioavailability of essential and toxic trace elements. Federation Proceedings, 42:1714.

Olson P. A.; D. R. Brink; D. T. Hickok; M. P. Carlson; N. R. Schneider; G. H. Dentscher; D. C. Adams; D. J. Colburn and A. B. Johnson (1999). Effect of supplementation of organic and inorganic combination of copper, cobalt, manganese and zinc about nutrient requirement levels on postpartum two year old cows. J. Anim. Sci., 77(3): 522-532.

Riordan J. F. and B. L. Vallee (1976). Structure and function of zinc metalloenzymes .In: Trace elements in Human and diseases-prased As, 1:227.

Robinson P. H.; W. Chalupa; C. J. Sniffen; W. E. Juliens; H. Sato; T. fujieda; T. Uedo and H. Suzuki (2002). Influence of abomasal infusion of high levels of lysine, methionine or both on ruminal fermentation eating behavior and performance of lactating dairy cows. J. Anim. Sci., 78:1067-1077.

Salem F. A. (2003). Effect of dietary silage source on feed intake, nutrients digestibility, some blood constituents and milk production in lactating buffaloes. Egypt. J. Nut. and Feeds, 6:5.

SAS (1985). SAS / STAT user's Guide: statistics. $4^{\text {th }}$ Ed., SAS institute Inc., Cary, NC.

Schneider B. H. and W. P. Flatt (1975). The evaluation of Feeds Through Digestibility Experiments. The University of Georgia Press Athens 30: 602 
Shakweer I. M. E.; A. A. M. EL-Mekass and H. M. EL-Nahas (2010). Effect of zinc supplementation as zinc sulfate or zinc methionine on Friesian calf performance. Egyptian J. Anim. Prod., 47(1): 23-36.

Siciliano-Jones J. L.; M. T. Socha; D. J. Tomlinson and J. M. DeFrain (2008). Effect of trace mineral source on lactation performance, claw integrity, and fertility of dairy cattle. J. Dairy Sci., 91:1985-1995.

Sorensen J. R. J. (1987). A physiological basis for pharmacological activities of copper complexes: a hypothesis. In: Sorensen J R J (Editor), Biology of Copper Complexes. Human Press, Clifton, NJ, 3.

Spears J. W. and W. P. Weiss (2008). Role of antioxidants and trace elements in health and immunity of transition dairy cows. Vet. J., 176:70-76.

Valdes C.; M. D. Carro; M. J. Ranitta and J. S. Gonzulez (2000). Effect of forage to concentrate ratio in complete diets offered to sheep on voluntary food intake and some digestive parameters. J. Anim. Sci., 70:199.

Vallee B. L. and K. H. Falchuk (1993). The biochemical basis of zinc physiology. Physiol. Rev., 73:79-118.

Van Keulen J. and B. A. Young (1977). Evaluation of acid insoluble ash as a natural marker in ruminant digestibility studies. J. Anim. Sci., 44:282.

Ward M. and G. Lardy (2005). Beef Cattle Mineral Nutrition This publication gives a brief overview of minerals that have the greatest impact on livestock productivity AS-1287.

Weichselboum F. (1946). Colorimetric determinted of total protein .An.J.Clin.Path., 16.40.

Zapsalis C. and R. A. Beck (1985). Copper. In: Food Chemistry and Nutritional Biochemistry Journal Wiley and Sons, New York 10091021.

Zeedan Kh. I. I.; O. M. EL-Malky ; O. Farghaly; M. AbdEL-Rahman; M. Abdel-Lateuf and Abo-elenen I.M.Ebtehag (2008). Effect of biogen-zinc supplementation some production ,digestion, rumen fermentation and some blood parameters in buffalo $14^{\text {th }}$ scientific conference of ESAP \& $3^{\text {rd }}$ Scientific Conference of APRI Cairo,17-18 December. 


\section{EL-Nahas H. M.}

تـأثير إضـافة كبريتـات الزنـك و/أو كبريتـات المنجنيزعلى الاداء الانتـاجى للعجول الفريزيان

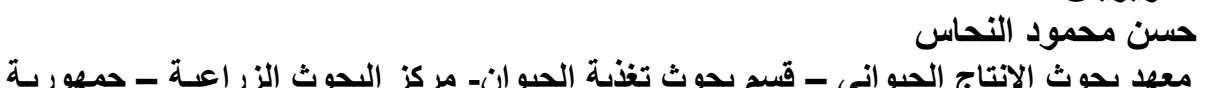
مصر العربية الإتكاج الحيو اني - معت بحوت تغذية الحيوان- مركز البحوث الزراعية - جمهوريـة أجريت هذه الدراسة بهدف دراسة تأثير إضـافة كبريتات الزنكا و أو كبريتات المنجنيز

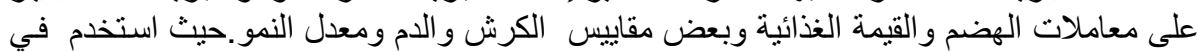

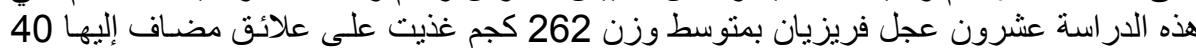

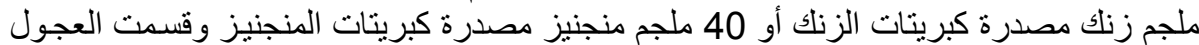

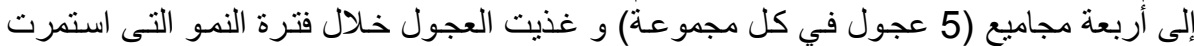
180 يوما على النحو النالي :-

1. مجموعة المقارنة غذيت على علف مركز + دريس برسيم + قش الأرز بدون إضـافات طبقا

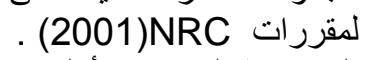

2. المجموعة المختبرة الأولى غذيت على عليقة المقارنة +40 ملجم كبريتات الزنك /كجم مـادة جافة ماكولة .

3. المجموعة المختبرة الثانية غذيت على عليقة المقارنة +40 ملجم كبرينات المنجنيز /كجم مادة جافة مأكولة.

4. المجموعة المختبرة الثالثة غذيت على عليقة المقارنة +40 ملجم كبريتات الزنك +40 ملجم كبريتات المنجنيز /كجم مادة جافة مأكولة النئ.

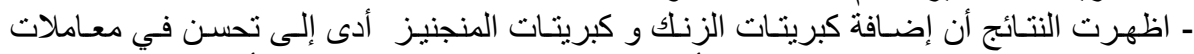

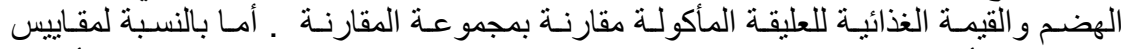

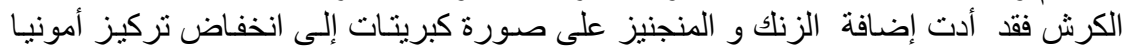

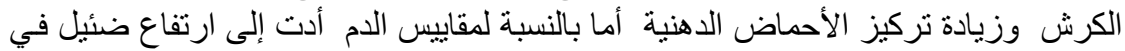

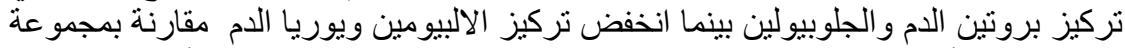

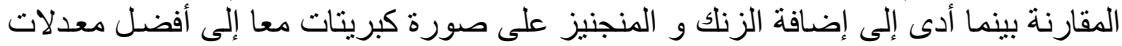

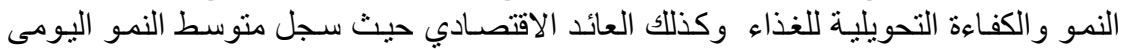
مقدار 1.037 كجم ، 7.1 كجم مادة جافة/كجم نمو مع 2.8\% كفاءة الكاءة اقتصادية.

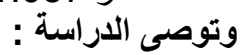

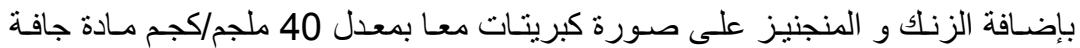

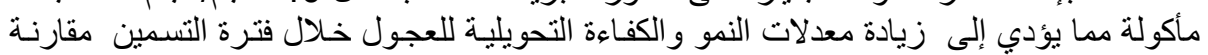

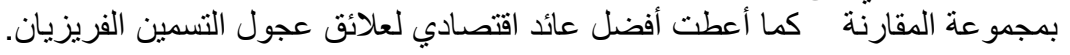

